\title{
University-industry research collaboration in the Brazilian oil industry: the case of Petrobras*
}

Giovanna Guimarães Gielfi*

André Tosi Furtado***

André Sica de Campos ${ }^{* * * *}$

Robert J. W. Tijssen ${ }^{* * * *}$

\begin{abstract}
This paper examines research collaboration between the Brazilian state-controlled oil company, Petrobras, and universities from 1980 to 2014. Despite the importance of universityindustry research collaboration in Brazilian oil industry, there are few comprehensive and long-time spam studies on this topic. This paper helps to fill a gap in the academic literature by providing comparative historical data on research collaboration between Petrobras and Brazilian universities. Based on the co-authored publications by Petrobras we analyze changes in intensity of this collaboration and its geographical orientation, inter-organizational level and scientific knowledge base. Furthermore, we address the issue of whether changes in Brazilian $\mathrm{R} \& \mathrm{D}$ funding policy have affected trends in collaboration. Our findings show an increasing

* This work was supported by Capes Foundation [BEX 10715/14-2]. The first author also would like to thank the National Council for Scientific and Technological Development (CNPq) for the regular PhD scholarship in Brazil. The authors would like to thank Alfredo Yegros and Clara Calero-Medina for their assistance and technical support to the data analysis.

** Universidade Estadual de Campinas (Unicamp), Campinas (SP), Brasil. E-mail: giovannagielf@ige.unicamp.br.

*** Universidade Estadual de Campinas (Unicamp), Campinas (SP), Brasil. E-mail: furtado@ige.unicamp.br.

**** Faculdade de Ciências Aplicadas/Universidade Estadual de Campinas (FCA/Unicamp), Limeira (SP), Brasil. E-mail: andre. campos@fca.unicamp.br

***** Centre for Science and Technology Studies (CWTS), Holanda. E-mail: tijssen@cwts.leidenuniv.nl.
\end{abstract}


collaboration between Petrobras and Brazilian universities, resulting in an enlargement of the company's network collaboration and reinforcing its knowledge base.

KeYwords | University-Industry Collaboration; Co-Authorship; Network Analysis; Brazil; Oil Industry

JEL CODES | O30; O32; O38

\section{A interação universidade-empresa na indústria de petróleo brasileira: o caso da Petrobras}

\section{RESUMO}

Este artigo analisa a colaboração em pesquisa entre a empresa estatal petrolífera brasileira, Petrobras, e universidades no período de 1980 a 2014. Apesar da importância da interação universidade-empresa na indústria de petróleo brasileira, há poucos estudos temporalmente abrangentes sobre o tema. Este trabalho ajuda a preencher uma lacuna na literatura, provendo dados comparativos de longo prazo sobre a colaboração em pesquisa entre a Petrobras e universidades. Baseando-se nas publicações da Petrobras em coautoria com universidades, são analisadas as mudanças na intensidade e orientação geográfica da colaboração, no nível de relação interorganizacional e na base de conhecimentos da empresa. Além disso, o trabalho também aborda os efeitos da recente política de financiamento à pesquisa e desenvolvimento na interação. Os resultados mostram uma crescente interação entre a Petrobras e as universidades brasileiras, levando a um alargamento da rede de colaborações científicas da empresa e reforçando sua base de conhecimentos.

PALAVRAS-CHAVE | Interação Universidade-Empresa; Coautoria; Análise de Redes Sociais; Brasil; Indústria do Petróleo

Códigos JEL | O30; O32; O38 


\section{Introduction}

University-industry linkages have grown in importance as a central concern for policy makers and university boards since the 1980s (OECD, 1990). Awareness of the potential economic benefits from university-industry collaboration have prompted many countries to promote policies to support these relationships (OECD, 2013; YUSUF; NABESHIMA, 2006). Such initiatives are based on the expectation that university-industry collaboration can increase economic competitiveness, given the acknowledgement of the role played by universities and other public research organizations in supporting the catching up process across countries and sectors (MAZZOLENI; NELSON, 2007).

Following these trends, in recent decades the Brazilian government has promoted policies to foster university-industry collaboration (RAPINI, 2007). Yet, some authors have argued that limited success has been achieved in the promotion of university-industry collaboration and private R\&D funding (VELHO; VELHO; SAENZ, 2004). Thus, since 2000, Brazil has adopted a set of new legal and regulatory framework to incentivize university-industry collaboration ${ }^{1}$.

Nevertheless, Brazil has lagged behind other OECD countries in terms of scientific and technological outputs (OECD, 2014). Recent survey-based studies have shown that the pattern of university-industry collaboration is narrow, with interaction limited to a few sectors (FERNANDES et al., 2010; SUZIGAN; ALBUQUERQUE, 2011a, 2011b)start ups and incubators. These observations are confirmed by the Brazilian Innovation Survey 2011 (PINTEC), pointing out that although collaboration on innovation increased from 2008 to 2011 (from $10,1 \%$ to $15,9 \%$ of innovative industrial firms have collaborated with some kind of partner on innovation), only 30\% of Brazil's innovative industrial firms rated the collaboration with universities as highly important (IBGE, 2013). Brazil underperforms other OECD countries in terms of percentage of innovative firms collaborating on innovation with higher education or government research institutions (OECD, 2013).

1 In 2004, the so called "Lei da Inovação" (Law n. 10.973/04) was passed, which set the general regulations to commercialize public research outputs; and in 2005, the "Lei do Bem" (Law n. 11.196/05) provided the framework for financial incentives to private investments in innovation. In 2007, the Science and Technology Plan (PACTI) stressed the importance of public support to industrial innovation and the role of universities in this process (BRASIL, 2007), and this has been reinforced in the Science and Technology Plan 2012-2015 (ENCTI) (BRASIL, 2012). 
University-industry collaboration in Brazil is characterized by a markedly uneven geographical distribution (GARCIA et al., 2015) and concentration in mining, oil and petrochemicals, agribusiness, and aerospace industries. These specific cases have relied on long-term relationships between firms and public research organizations (SUZIGAN; ALBUQUERQUE, 2011a). Contrary to conventional wisdom, these findings reveal the importance of university-industry linkages in the so called low and medium-tech industries (or mature industries) became evident (CHAVES et al., 2012; RAPINI et al., 2009), where relationships are based on well-established contacts and supported by public research funding (BODAS FREITAS; MARQUES; SILVA, 2013).

The oil industry case is particularly important to illustrate the specificities of university-industry collaboration in Brazil. The Brazilian state-controlled oil company, Petrobras, was created in 1953 to monopolistically exploit oil reserves, refining and transport (distribution was open to private companies). Since then, Petrobras has established a consistent relationship with several universities in Brazil, reported in case studies that have focused on specific research-intensive institutions (LIMA; SILVA, 2012; POLETTO; ARAÚJO; MATA, 2011; SUSLICK, 2007; TURCHI; DE NEGRI; DE NEGRI, 2013). Also, previous studies show that collaboration on $R \& D$ with different partners, including universities, was crucial for Petrobras to catch up from being an 'imitator' to becoming one of the 'frontier innovators' in oil industry (DANTAS; BELL, 2011; FURTADO; FREITAS, 2000; GIELFI et al., 2013). Results from PINTEC 2011 reinforce the importance of collaboration with universities to innovative firms in coke and oil industry, as about $37 \%$ of innovative firms in the sector reported collaborations with Brazilian universities in the period 2009-2011. This contrasts positively with the overall average of $6,5 \%$ of innovative industrial firms reporting collaborations with universities to innovate (IBGE, 2013).

Besides this historical relationship between Petrobras and academia, changes in the regulatory framework have ensured continued funding earmarked to $R \& D$ activities carried out by Brazilian universities and research institutes with the creation of the Oil and Gas Sectoral Fund (CT-Petro) and the ANP R\&D Clause. Despite this historical relationship between Petrobras and academia, which is now fostered by S\&T policy, there is a surprising lack of comparative historical data on research collaboration between Petrobras and Brazilian universities. The aim of this paper is to fill this gap and analyze the main trends in terms of university-industry collaborations over the last 35 years using bibliometric data. 
Therefore, we question whether Petrobras has increased research collaboration with universities, and, if so, to what extent it has changed in terms of geographical orientation, inter-organizational level and scientific knowledge base. In so doing we wanted to explore the existence of evidence suggesting that changes in R\&D funding policy have affected trends in collaboration. In other words, we sought to investigate whether the number of university-industry co-publications (UICs) meaningfully changed after the establishment of R\&D funding instruments.

In particular, we focus on the nature and intensity of research collaboration. We use UICs as an information source to measure the magnitude and intensity of collaborative linkages. We analyze how the characteristics of collaboration vary over time in terms of partners, geographical orientation and embeddedness, and the distribution across scientific fields. We wanted to check whether the growth in funding R\&D activities carried by Brazilian universities and research institutes might have helped to foster Petrobras-university collaboration. In order to do so, the paper is organized as follows. Section two introduces the analytical framework that guided our analysis. Section three discuss the R\&D funding policy. Section four explains the method and section five presents the data. Section six concludes the paper discussing research and practical implications.

\section{Analytical framework}

Universities are considered a key actor in innovation systems (MOWERY; SAMPAT, 2005). They are recognized as important sources of knowledge and skills, especially for R\&D-intensive industries (KLEVORICK et al., 1995; MANSFIELD, 1995). The generic contributions of universities also include the provision of engineering knowledge, the development of new methodologies and instrumentations and also spin-off company generation (PAVITT, 1991; SALTER; MARTIN, 2001)

In addition, universities and firms present different rationales and motivations to interact with each other. In the case of universities, incentives include access to additional funding and resources and enhancement of research and teaching quality. On the other hand, the main reasons for firms to interact are to attract and hire human resources or to gain access to new scientific knowledge and university staff and facilities (ARZA, 2010; DUTRÉNIT; ARZA, 2010). Furthermore, empirical research shows that public funds for R\&D is an important determinant of collaboration (BEKKERS; BODAS FREITAS, 2008) and it is able to influence the motivations 
of collaboration leading to participate in high-risk projects (RAPINI; OLIVEIRA; SILVA NETO, 2014).

The research literature emphasizes the varied nature of university-industry links and points out that these links are often used simultaneously and in succession (COHEN; NELSON; WALSH, 2002; MEYER-KRAHMER; SCHMOCH, 1998). Furthermore, empirical evidence shows that these links and their intensity differ across countries (ALBUQUERQUE et al., 2015; DUTRÉNIT, 2010), and these connections are often sector - and/or technology - specific (BEKKERS; BODAS FREITAS, 2008; LAURSEN; SALTER, 2004).

These links, also called "channels" or "mechanisms", involve different degrees of formality in the organizational agreements and personal contacts (SCHARTINGER et al., 2002), and encompass different types of knowledge (TIJSSEN, 2005). It is argued that the adoption of specific links is related to the goals of university and firms and their motivations to interact (ARZA, 2010). Also, differences in their potential to enhance knowledge diffusion at the local economy render some links more valuable than others (GIULIANI; ARZA, 2009). Moreover, not all kinds of links require interaction or collaboration between university and firms (PERKMANN; WALSH, 2009).

Due to this heterogeneity in linkages and modes of interaction, there are methodological challenges in measuring and assessing the diversity within universityindustry collaborations. This methodological challenge is compounded by problems of data availability and measurability. For this reason, to focus on research collaboration between university and industry we adopt co-authored publications as a measure of magnitude and intensity of collaboration.

These co-authorship data have been used as a proxy for collaboration in a wide range of studies since the 1990s (TIJSSEN, 2012), but there are some noteworthy drawbacks. First, not all collaborative research results in co-authored papers, thus studies based on co-publication risk missing forms of collaboration that do not result in co-publication. Second, co-authorship is not a synonym for collaboration (KATZ; MARTIN, 1997), which means that sometimes the authors had not actually collaborated on research. Thirdly, co-authorship may reflect other academic practices and behaviors. Thus, a co-authored publication may be a way to compensate, for example a quid pro quo for supplying resources (e.g. research data or materials, money) or intellectual debts due to mentorships. Or yet, a way to gain legitimacy or access research networks (COCKBURN; HENDERSON, 1998).

Notwithstanding these issues, there is a growing consensus that co-publications could provide a reasonable proxy measure for university-industry research cooperation 
(CALVERT; PATEL, 2003). Also, validation studies have shown that co-publications data enable meaningful comparisons for international benchmarking (TIJSSEN; VAN LEEUWEN; VAN WIJK, 2009). In addition, the growing adoption of this indicator by governments and assessment organizations in their policy reports has helped to spread its usage. For example, it is used in the Innovation Union Scoreboard produced by the European Commission, to help monitor innovative performance within Europe (EUROPEAN COMMISSION, 2015), and in the Science, Technology and Industry Outlook produced by OECD $(2002,2014)$. In Brazil, science and technology indicators reports mainly use co-publications data to analyze scientific collaboration (FAPESP, 2011).

\section{R\&D funding policy in the Brazilian oil industry}

Innovation policy is perceived in the literature either as an instrument to simply correct market imperfections, due to conditions of uncertainty, risk or lack of appropriability, or as a way to focus on increasing interaction across different actors (ROCHA, 2015). The first approach understands R\&D public funding as counteracting the tendency of firms to under-invest in research (especially, in basic research) due to market failures and to the characteristics of innovative activities, such as risk and uncertainty (ARROW, 1962). Furthermore, the fact that innovative activities are marked by uncertainty and mainly funded by the reinvestments of profits by the firms (FREEMAN; SOETE, 1997) - as capital market fails at funding it - supports the argument pro-public funding of R\&D in order to complement and stimulate private $R \& D$ expenditures. The second approach recognizes the interactive nature of innovation and emphases the government policy role on building innovative networks - the US case provides an example of the key role played by governmental policy to foster innovation (MAZZUCATO, 2013).

Brazilian oil industry provides a notorious example of the role of government policy on fostering innovation. This case is particularly important to illustrate the specificities and effects of R\&D funding policy on the innovation system. Since the liberalization of sector, innovation policy related to oil and gas activities has been oriented to promote interactions between oil companies, suppliers and universities. Procurement policy of the state-owned oil company, Petrobras, has been used to increase the company's interactions with local suppliers. Nonetheless, this policy has been unable to push the production of R\&D-intensive equipment (RIBEIRO; FURTADO, 2014). In addition, several innovation policy instruments have been 
set towards the oil sector, such as PROMINP and Inova Petro. This paper focuses on those created to foster university-industry research collaboration in the Brazilian oil industry - i.e. the Oil and Gas Sectoral Fund and the ANP R\&D Clause.

In 1997, the "Petroleum Law" (Law n. 9.478/97) brought monopoly to an end and in return created the Oil and Gas Sectoral Fund ${ }^{2}$ (PEREIRA, 2005; PEREIRA; FIGUEIREDO, 2006). A share of $25 \%$ of any additional royalty revenues resulting from the Law was directed to science and technology, and this resource financed the Oil and Gas Sectoral Fund. The Fund assigned resources to promote university-industry collaboration but R\&D investments have not increased accordingly (FURTADO, 2008).

In addition, the National Petroleum Agency (ANP - responsible for regulating the oil sector), included an "R\&D clause" in new concession contracts concerned with the exploration and production of oil and gas, which established that any such firm (including Petrobras) must invest on R\&D a minimum of $1 \%$ of their gross revenue generated by oil fields with high profitability or high productivity (ANP Clause n. 24, Resolution No. 33/2005 and 34/2005). At least half of this sum must be invested in public or private Brazilian-based universities or research institutes accredited by the ANP. From 2006 to 2015, the funds destined to $\mathrm{R} \& \mathrm{D}$ in Brazilian universities and research organizations generated by the ANP $\mathrm{R} \& \mathrm{D}$ clause $^{3}$ totalized over BRL 4,6 billion (approximately $€ 1,3$ billion). Of this amount, 93\% (BRL 4,3 billion, approximately $€ 1,2$ billion) relate to Petrobras. Furthermore, Petrobras spent $€ 833,6$ million on R\&D activities in 2013, becoming the leading national company in terms of $R \& D$ investment (EUROPEAN COMMISSION, 2014).

Although the Oil and Gas Sectoral Fund and the ANP R\&D Clause serve the same purpose, it is worth stressing the significant difference in the amount of resources between them, exhibited in Figure 1. Due to disturbances in the Brazilian economy at the period, the Oil and Gas Sectoral Fund had a share of its resources redirected to increasing primary surplus (FURTADO, 2003), which has hampered its performance. Furthermore, the Royalties Law was passed in 2012 and delivered

2 Recognized as a landmark in Brazilian science and technology system, the implementation of the Science and Technology Sectoral Funds aiming to provide more stable financial resources for science and technology activities in the country (VIEIRA, 2001). The Oil and Gas Sectoral Fund was first to be created by the Ministry of Science and Technology in 1999. Information on revenues and executed investments of Oil and Gas Sectoral Fund are available on the Brazilian Ministry of Science, Technology and Innovation website: <www.mct.gov.br>.

3 For additional information on the ANP R\&D Clause: <www.anp.gov.br>. 
the final blow to the Fund, voiding its source of resources. On the other hand, the ANP R\&D Clause has been consolidated as the main R\&D funding instrument directed to oil and gas activities.

FIGURE 1

Trend in R\&D funding policy related to oil industry (BRL million real value) - 2001-2015

Oil and Gas Sectoral Fund ANP R\&D Clause

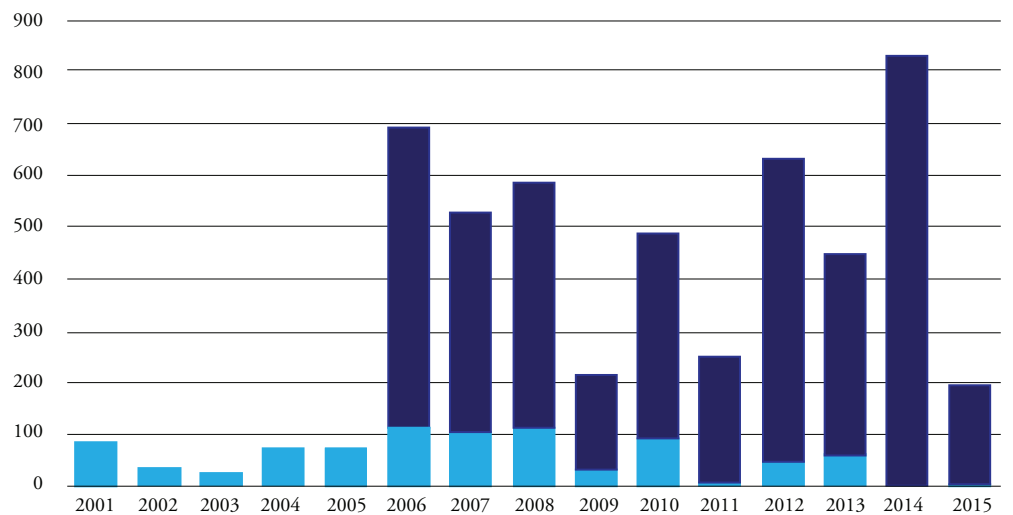

Source: ANP and MCTI.

In order to manage the resources from the ANP "R\&D clause", and to orient its collaborative $\mathrm{R} \& \mathrm{D}$ projects with Brazilian universities and research organizations, Petrobras launched a model of scientific and technological networks in 2006 which was called Thematic Networks. These partnerships included the creation of cutting-edge laboratories, research training and project development. Studies suggest that these collaborative networks with universities have helped to foster innovation and knowledge creation (FERREIRA; RAMOS, 2015; POLETTO; ARAÚJO; MATA, 2011). Moreover, Petrobras' investments on universities have an undeniable impact on the scientific and technological capabilities of the Brazilian universities, supporting the creation and the refurbishment of laboratories and other research facilities, and broadening the research agenda of universities through the inclusion of at least 40 new research areas (TURCHI; DE NEGRI; DE NEGRI, 2013). 


\section{Data and methodology}

Our results are based on bibliographic data extracted from Petrobras' authored publications that were published in journals indexed by the CWTS-licensed offline version of Thomson Reuters' Web of Science Core Collection (WoS) database. ${ }^{4}$ The dataset includes all Petrobras' (co-)authored publications consisting of research articles and reviews from 1980 to 2014. A total of 1,431 records were retrieved and further processed to clean and standardize the institutional affiliate address information. Publications were assigned to a standardized organization name on basis of their author addresses in the by-line of these publications. All indicated organization addresses were considered, thus a publication can be authored by multiples organizations, but they are all (co-)authored by Petrobras.

Using the author affiliate address, publications were categorized as university-industry co-publications (UIC) when co-authored by Petrobras and at least one university. It is worth stressing that UICs do not include non-university research institutes. The dataset of UIC publications was classified in terms of geographical collaboration as 'national' or 'international' collaboration. UICs were classified as 'national' when including at least one Brazilian university, and 'international' when including at least one foreign university. Thus, a single UIC may have multiple classifications if several universities are mentioned in the author address. The 'UIC intensity' indicator was calculated as the ratio of publications co-authored with a university to the total number of Petrobras' authored publications. We also calculated 'national UIC intensity' and 'international UIC intensity' for each period.

As for subject areas, publications were classified according to the Thomson Reuters Journal Subject Categories. Each publication belongs to one, or sometimes to more than one, of these 'fields of science' which are defined by the journals where they were published. The Petrobras' collaboration networks were created using UCINET software.

4 This version of the database includes the Science Citation Index Expanded, the Social Sciences Citation Index, and the Arts and Humanities Citation Index. 


\section{Results}

Our analysis is focused on longer-term developments of Petrobras' research collaboration with universities. Figure 2 shows the general trend in the total number of publications by Petrobras and UICs from 1980 to 2014. The graph shows an increase in Petrobras' publication output, especially since 1999, when the number of publications doubled compared to the previous year (see Annex section of this paper). UICs represent $85.6 \%$ of the total number of Petrobras' publications over the period. In other words, the vast majority of the scientific research publications by Petrobras are based on university-industry cooperation.

FIGURE 2

Trend in Petrobras' (co-)authored publication output - 1980-2014

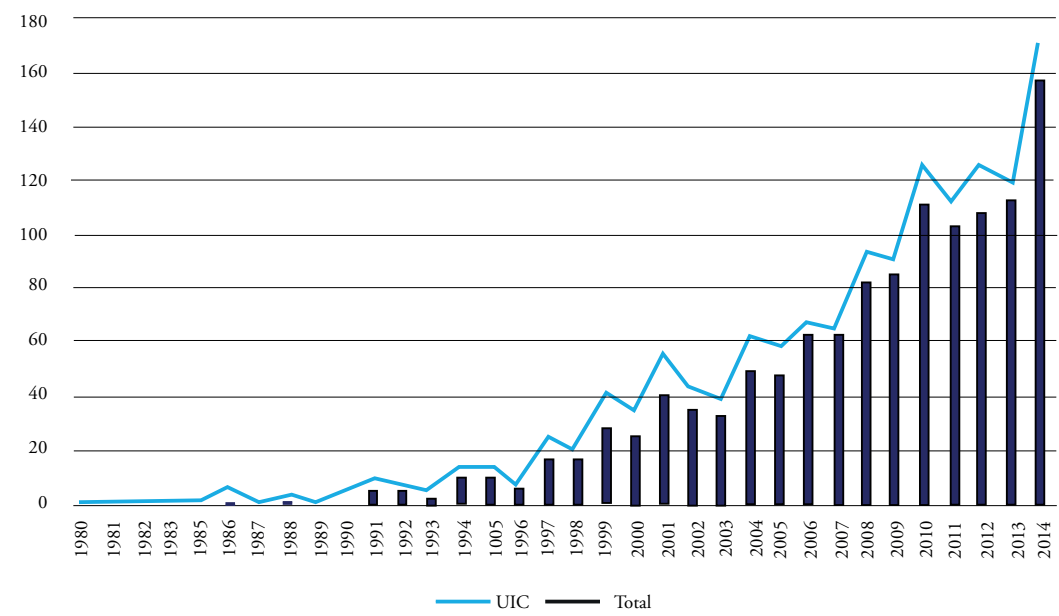

Source: Authors based on CWTS Web of Science database.

To capture policy changes in the Brazilian oil industry, as well as its potential effects on collaboration between Petrobras and universities, the trends are divided into three policy phases following the changes in the oil and gas regulatory framework regarding funding to $R \& D$ activities carried out by Brazilian universities and research institutes. Thus, the 1980-1998 phase encompasses the period in which Petrobras monopolized oil and gas exploration and production activities in Brazil. This phase is characterized by absence of a specific science and technology sectoral policy to oil and gas industry, and innovation efforts were very centralized on Petrobras. The last two phases reflect changes in the regulatory framework regarding funding to R\&D activities carried out by Brazilian universities and research institutes. The 
1999-2005 phase is marked by the establishment of the Oil and Gas Sectoral Fund; the subsequent phase (2006-2014) by the implementation of the R\&D clause by the National Petroleum Agency (ANP). Due to the small number of publications during the first phase, our analysis has focused the years ranging from 1999 to 2014, which concentrates $91 \%$ of the total publication output by Petrobras.

We expect that the R\&D funding policy affects Petrobras-university collaboration, lading to an increase in the number of co-publications. Due to the significant differences in the amount of resources between the Oil and Gas Sectoral Fund and the ANP R\&D Clause exhibited in Figure 1, we also expect that the UIC growth rate from the third phase surpasses the one from the second phase.

Table 1 exhibits, for each of the phases, changes in UIC output and its breakdown in the geographical distribution of UIC partners. The total number of publications in each period has an upward tendency. The significant increase in the number of publications from the second phase to the third phase onwards reflect the effects of changes in oil and gas related to R\&D funding, and in the collaboration-promoting framework conditions taken place in Brazil since the 2000s. Funds destined to R\&D in Brazilian universities and research organizations generated by the ANP R\&D clause have grown in average 16\% per year during 2006-2015. These resources are projected to increase from BRL 0,5 billion in 2013 to BRL 1,75 billion in 2022 (approximately from $€ 114$ million to $€ 401$ million) (ANP, 2013). The growing importance of collaboration with universities in the publishing activity of Petrobras is shown by the increasing number and intensity of UICs overtime, from $78 \%$ of total to $91 \%$ of total publications during the years $1999-2014$.

TABLE 1

Petrobras-university research collaboration trends - 1980-2014

\begin{tabular}{lrrrr}
\hline \multicolumn{1}{c|}{ Phase/output-intensity } & (1) 1980-1998 & (2) 1999-2005 & (3) 2006-2014 \\
\hline Petrobras publication output & 124 & 334 & 973 \\
UIC publication output & 77 & 259 & 890 \\
National UIC output & 47 & 211 & 797 \\
International UIC output & 35 & 78 & 187 \\
UIC intensity (\%) & 62.0 & 78.0 & 91.0 \\
National UIC intensity (\%) & 38.0 & 63.0 & 82.0 \\
International UIC intensity (\%) & 28.0 & 23.0 & 19.0 \\
\hline
\end{tabular}

Source: Authors based on CWTS Web of Science database. 
Our results also reveal a remarkable upward trend in the national orientation of collaboration. The number and intensity of UICs reveal the prominent role played by Brazilian universities in collaboration with Petrobras. Although the number of national and international UICs (as a whole) has increased, only the collaboration with Brazilian universities (national UIC intensity) has increased in terms of intensity.

Thus, the geographical distribution of UICs tends to reflect the existence of localized knowledge flows, and the fact that collaboration may be shaped by geographical proximity. Also, the national orientation of collaboration sheds light on policy effects on collaboration and in the university research system. As pointed before, the establishment of new mechanisms to fund R\&D earmarked to Brazilian institutions.

Table 2 displays the main university research partners of Petrobras by listing the universities with 10 or more publications in the period. Of the 27 universities listed, the bulk is comprised of public institutions and only two are not from Brazil (University of Tulsa in the United States, and the University of Liege in Belgium). The table also combines UIC data with information of R\&D funding policy to examine how funding distribution across universities affects Petrobras' collaboration at inter-organizational level. Results point to a close relation between R\&D funding and UIC intensity, making the effect of R\&D funding policy on Petrobras-universities collaboration clear.

To examine how collaboration evolves over time at the inter-organizational level, Figure 3 shows the Petrobras' collaboration networks for each phase. Represented in the networks are the universities which have 10 or more co-publications in collaboration with Petrobras. Our results show that from 1999 to 2005, only 6 universities were listed as high-frequency Petrobras UIC partners. The number of these UIC partners substantially changed in the next phase (2006-2014), as a group of 10 universities emerges among the high-frequency partners. This development illustrates a broadening in Petrobras' research network, which has expanded from 6 to 16 partners during the period. Petrobras' established partners are indicated by a squared node red colored; while the emergent partners are represented by the grey color. 
TABLE 2

Petrobras' most active partners - 1999-2014 (UIC output >=10)

\begin{tabular}{|c|c|c|c|c|}
\hline Universities & $\begin{array}{c}\text { Number of } \\
\text { UIC }\end{array}$ & $\begin{array}{c}\% \text { UIC } \\
\text { intensity }\end{array}$ & \% CT-Petro & $\begin{array}{l}\% \text { ANP } \\
\text { Clause }\end{array}$ \\
\hline Univ. Fed. Rio de Janeiro & 416 & 31.8 & 6.9 & 11.2 \\
\hline Univ. Estadual Campinas & 108 & 8.3 & 0.7 & 2.7 \\
\hline Univ. São Paulo & 93 & 7.1 & 1.7 & 2.1 \\
\hline Pont. Univ. Católica Rio de Janeiro & 79 & 6.0 & 3.5 & 3.4 \\
\hline Univ. Fed. Fluminense & 67 & 5.1 & 0.6 & 1.7 \\
\hline Univ. Fed. Rio Grande do Sul & 65 & 5.0 & 1.4 & 2.2 \\
\hline Univ. Estado Rio de Janeiro & 54 & 4.1 & 0.3 & 1.1 \\
\hline Univ. Estadual Norte Fluminense & 32 & 2.4 & 0.3 & 0.7 \\
\hline Univ. Fed. Santa Catarina & 27 & 2.1 & 1.7 & 2.7 \\
\hline Univ. Fed. Rio Grande do Norte & 26 & 2.0 & 4.0 & 2.5 \\
\hline Univ Fed Minas Gerais & 24 & 1.8 & 1.2 & 0.8 \\
\hline Univ. Fed. Espírito Santo & 22 & 1.7 & 0.5 & 1.2 \\
\hline Univ. Fed. Santa Maria & 21 & 1.6 & 0.1 & 0.2 \\
\hline Univ. Estadual Paulista & 20 & 1.5 & - & 0.5 \\
\hline Univ. Fed. Bahia & 17 & 1.3 & 1.9 & 1.1 \\
\hline Univ. Fed. São Carlos & 17 & 1.3 & 0.1 & 1.2 \\
\hline Univ. Fed. Paraná & 16 & 1.2 & 0.3 & 0.6 \\
\hline Univ. Fed. Pernambuco & 14 & 1.1 & 4.0 & 3.5 \\
\hline Univ. Fed. Ceará & 14 & 1.1 & 1.7 & 0.7 \\
\hline Univ. Fed. Goiás & 14 & 1.1 & 0.7 & 0.2 \\
\hline Univ. Fed. Juiz de Fora & 12 & 0.9 & 0.0 & 0.1 \\
\hline Inst. Mil Engn & 10 & 0.8 & 0.2 & 0.5 \\
\hline Univ. Fed. Pará & 10 & 0.8 & 0.4 & 0.3 \\
\hline Univ. Brasília & 10 & 0.8 & 0.3 & 0.8 \\
\hline Univ. Fed. Rural Rio de Janeiro & 10 & 0.8 & 0.2 & 0.7 \\
\hline Univ. Liege (Belgium) & 10 & 0.8 & - & - \\
\hline Univ. Tulsa (United States) & 10 & 0.8 & - & - \\
\hline
\end{tabular}

Source: Authors based on CWTS Web of Science database, ANP and MCTI

Our results also indicate that changes in Petrobras' collaboration networks go beyond the inclusion of new partners: not only were more universities integrated into the network, they have also become more interconnected (Fig.3b). This finding is supported by some measures of centrality presented in Table 4. We calculated 
three main measures of centrality and each of them tend to capture different aspects of the position that an university has in the network: centrality degree tells us how well connected an university is; closeness centrality indicates how easily an actor can reach other nodes; betweenness centrality reveals how important a university is in terms of connecting other universities (JACKSON, 2008). From the statistics measurements, it is clear that the Federal University of Rio de Janeiro and the University of Campinas became central actors in Petrobras' research network, as they have the largest number of direct connections with other actors (centrality degree). Furthermore, the betweenness centrality shows that the Federal University of Rio de Janeiro is the most "central" actor in Petrobras' research network in terms of connecting the other pairs of partners.

FIGURE 3

Petrobras' collaboration network: most active partners - 1999-2014 (UIC output >=10)

FIG. 3A 1999-2005

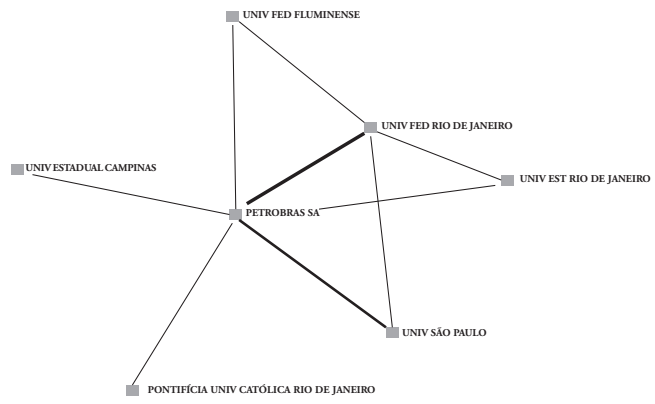

FIG. 3B 2006-2014

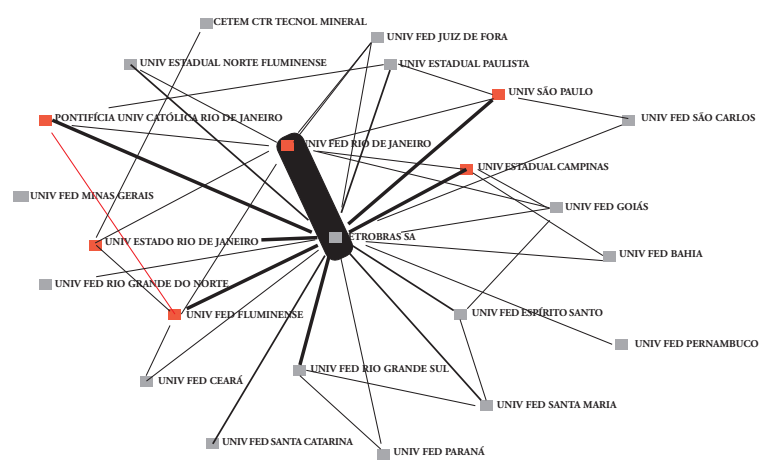

Source: Authors based on CWTS Web of Science database. 
TABLE 3

Normalized centrality measures of Petrobras' collaboration networks - 1999-2014

\begin{tabular}{|c|c|c|c|c|c|c|}
\hline \multirow[b]{2}{*}{ Universities } & \multicolumn{3}{|c|}{$1999-2005$} & \multicolumn{3}{|c|}{ 2006-2014 } \\
\hline & 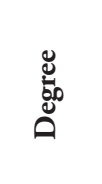 & 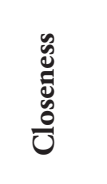 & 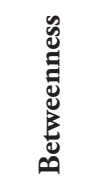 & 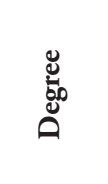 & 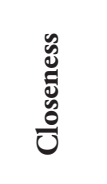 & 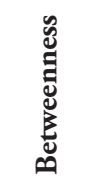 \\
\hline Petrobras & 0.3183 & 1.0000 & 1.0000 & 0.4357 & 1.0000 & 0.9881 \\
\hline Univ. Fed. Rio de Janeiro & 0.1700 & 0.5455 & 0.0000 & 0.1610 & 0.5385 & 0.0024 \\
\hline Univ. São Paulo & 0.0467 & 0.5455 & 0.0000 & 0.0367 & 0.5250 & 0.0000 \\
\hline Univ. Estadual Campinas & 0.0317 & 0.5455 & 0.0000 & 0.0424 & 0.5122 & 0.0000 \\
\hline Pont. Univ. Cat. Rio de Janeiro & 0.0300 & 0.5455 & 0.0000 & 0.0291 & 0.5122 & 0.0000 \\
\hline Univ. Fed. Fluminense & 0.0217 & 0.5455 & 0.0000 & 0.0257 & 0.5122 & 0.0000 \\
\hline Univ. Estado Rio de Janeiro & 0.0183 & 0.5455 & 0.0000 & 0.0267 & 0.5250 & 0.0000 \\
\hline Univ. Fed. Rio Grande do Sul & - & - & - & 0.0267 & 0.5122 & 0.0000 \\
\hline Univ. Estad. Norte Fluminense & - & - & - & 0.0129 & 0.5122 & 0.0000 \\
\hline Univ. Fed. Santa Catarina & - & - & - & 0.0124 & 0.5122 & 0.0000 \\
\hline Univ. Fed. Espírito Santo & - & - & - & 0.0105 & 0.5122 & 0.0000 \\
\hline Univ. Fed. Santa Maria & - & - & - & 0.0100 & 0.5122 & 0.0000 \\
\hline Univ. Fed. Minas Gerais & - & - & - & 0.0091 & 0.5122 & 0.0000 \\
\hline $\begin{array}{l}\text { Univ. Fed. Rio Grande do } \\
\text { Norte }\end{array}$ & - & - & - & 0.0091 & 0.5122 & 0.0000 \\
\hline Univ. Estadual Paulista & - & - & - & 0.0071 & 0.5122 & 0.0000 \\
\hline Univ. Fed. Goiás & - & - & - & 0.0067 & 0.5122 & 0.0000 \\
\hline Univ. Fed. Paraná & - & - & - & 0.0062 & 0.5122 & 0.0000 \\
\hline Univ. Fed. São Carlos & - & - & - & 0.0062 & 0.5122 & 0.0000 \\
\hline Univ. Fed. Ceará & - & - & - & 0.0057 & 0.5122 & 0.0000 \\
\hline Univ Fed Juiz De Fora & - & - & - & 0.0057 & 0.5122 & 0.0000 \\
\hline Univ. Fed. Pernambuco & - & - & - & 0.0052 & 0.5122 & 0.0000 \\
\hline Univ. Fed. Bahia & - & - & - & 0.0048 & 0.5122 & 0.0000 \\
\hline
\end{tabular}

Source: Authors based on CWTS Web of Science database.

Although these results are an interesting overview of the broadening of Petrobras-university research collaboration, what do they tell us about changes in the scientific knowledge base at Brazilian universities? To examine the extent 
and nature of this process, Table 4 shows a comparison of the top 20 scientific fields of publications by Petrobras with a breakdown into the established partners and emergent partners. Our results exhibit that the main fields of publications in collaboration with emergent partners scarcely differ from those with established partners. However, the emergent partners are relatively more important in fields of Metallurgy \& Metallurgical Engineering and Electrical \& Electronic Engineering.

TABLE 4

Top 20 scientific fields of publications with established and emergent university research partners - 2006-2014

\begin{tabular}{l|c|c|c}
\hline \multicolumn{1}{c}{ WoS Scientific fields } & $\begin{array}{c}\text { Petrobras } \\
\text { output }\end{array}$ & $\begin{array}{c}\text { Established } \\
\text { partners }\end{array}$ & $\begin{array}{c}\text { Emergent } \\
\text { partners }\end{array}$ \\
\hline Engineering; Chemical & 186 & 125 & 43 \\
Energy \& Fuels & 160 & 95 & 42 \\
Geosciences; Multidisciplinary & 89 & 35 & 29 \\
Chemistry; Physical & 78 & 49 & 19 \\
Chemistry; Multidisciplinary & 72 & 46 & 21 \\
Engineering; Petroleum & 70 & 28 & 11 \\
Materials Science; Multidisciplinary & 62 & 38 & 25 \\
Engineering; Mechanical & 62 & 47 & 10 \\
Environmental Sciences & 53 & 34 & 10 \\
Chemistry; Analytical & 52 & 35 & 18 \\
Geochemistry \& Geophysics & 51 & 16 & 11 \\
Mechanics & 39 & 32 & 7 \\
Thermodynamics & 37 & 29 & 8 \\
Biotechnology \& Applied Microbiology & 36 & 35 & 5 \\
Materials Science; Characterization \& Testing & 30 & 20 & 7 \\
Engineering; Electrical \& Electronic & 25 & 8 & 14 \\
Metallurgy \& Metallurgical Engineering & 23 & 9 & 5 \\
Polymer Science & 22 & 17 & 5 \\
Oceanography & 21 & 13 & 5 \\
Engineering; Environmental & 20 & 12 & 5 \\
\hline
\end{tabular}

Source: Authors based on CWTS Web of Science database.

Not only do these findings provide empirical evidence of the broadening in Petrobras' collaboration network, but they also reveal that the inclusion of the emergent 
partners into this network is helping to fill a gap, complementing the knowledge base by adding to the inputs and expertise provided by the established partners.

\section{Conclusions}

This paper analyzed the collaboration between Petrobras and universities from 1980 to 2014 with bibliometric data. The empirical results show an increasing collaboration between Petrobras and universities, which is mainly nationally oriented. We observe an influx of new Brazilian partner universities and a strengthening of ties in Petrobras' collaboration network. The enlargement of the network (inclusion of new partners) strengthens the scientific knowledge base in terms of research areas, as the emergent partners complement the expertise provided by the established partners. One might argue that large $\mathrm{R} \& \mathrm{D}$-active firms like Petrobras are mainly driven to increase research collaboration with universities in their search for new knowledge and research-based capabilities. In other words, expanding and/or diversifying the corporate $\mathrm{R} \& \mathrm{D}$ base. The emerging partners are the most likely candidates to bring new scientific knowledge to the R\&D portfolio of Petrobras.

Regarding the effects of changes in R\&D funding on collaboration trends since 1999, our results suggest that the establishment of sector-specific funds policy to support R\&D activities, carried out by Brazilian universities and research institutes, have fostered research collaboration. A comparison of the UIC output growth rates, for each development stage, reveals that the national UIC output has a higher growth rate than the overall UIC output. The growth of national UIC output also outpaces that of the publication output by Petrobras in all stages. Recognizing the importance of securing longer-term funding for research activities, Petrobras developed closer links with the university sector, which seem to be influenced and driven by the adopted R\&D funding policy.

The enlargement and strengthening of the Petrobras' collaboration networks may reflect a better integration of the entire Brazilian university research system in relation to oil and gas research activities. Furthermore, it becomes clear that public universities are making a contribution in areas such as engineering, applied areas of research and multidisciplinary research domains. Therefore, these public institutions, funded mainly with public resources, are engaged in generating scientific knowledge and know-how that is relevant to a strategic economic activity.

The policy initiatives of ANP are part of a long-term effort of the Brazilian state to enhance the R\&D resources and capabilities of Petrobras. This effort has 
gained momentum in recent years, with a more robust enlargement of the research network and a wider participation of Brazilian institutions.

However, this study has certain limitations owing to the rather narrow analytical approach adopted in this paper. UICs are at best a partial proxy for universityindustry research collaboration and, clearly, will never provide a complete picture of it. In view of these limitations, it should be stressed that our data analysis only allows us to address general features and trends of Petrobras-university research efforts and its scientific knowledge base. We cannot address many other factors not captured by UIC data that are likely to also impact university-industry linkages, such as the corporative strategy, and industrial and academic researchers' motivations to collaborate. In addition, we use a narrow definition of university-industry collaboration that does not include other public research organizations (PROs). Another limitation is that our proxy of collaboration includes only published papers in the WoS database, which means that we miss other relevant research outputs, such as patents and other forms of publications or papers in journals not included on the database.

In spite of the data limitations mentioned above, our empirical results raise a number of interesting unanswered questions. Follow-up interviews can be used to obtain qualitative information about motivations to collaborate; the fact that academic researchers at university need to publish their successful work in international journals in order to gain scientific prestige and rewards is arguably an important driving force of the UIC output. Interviews can also be used to explore the role of emergent partners in research and the role played by Petrobras' corporate strategy to structure and articulate its networks of collaboration.

Furthermore, this paper establishes scope to benchmark an international comparison between Petrobras and other oil companies. The extent to which our findings can be extended and generalized to global oil industry remains an open question for now. Further research is needed to analyze R\&D environment and dynamics in the global oil industry, and the importance of research collaboration with universities within this industry. Besides, this study can help fill a gap in the literature on university-industry collaboration, in which very little attention is given to university-industry collaboration in mature industries. 


\section{References}

ALBUQUERQUE, E. M. et al. (Ed.). Developing national systems of innovation: universityindustry interactions in the Global South. Cheltenham, UK and Northampton, MA: Edward Elgar, 2015.

ANP. Boletim ANP Petróleo e P\&D, n. 1, p. 1-22, ago. 2013.

ARROW, K. Economic welfare and the allocation of resources for invention. The rate and direction of inventive activity: economic and social factors. Cambridge, MA: National Bureau of Economic Research, 1962. v. I, p. 609-626.

ARZA, V. Channels, benefits and risks of public-private interactions for knowledge transfer: conceptual framework inspired by Latin America. Science and Public Policy, v. 37, n. 7, p. 473-484, Aug. 2010.

BEKKERS, R.; BODAS FREITAS, I. M. Analysing knowledge transfer channels between universities and industry: to what degree do sectors also matter? Research Policy, v. 37, n. 10, p. 1837-1853, Dec. 2008.

BODAS FREITAS, I. M.; MARQUES, R. A.; SILVA, E. M. D. P. E. University-industry collaboration and innovation in emergent and mature industries in new industrialized countries. Research Policy, v. 42, n. 2, p. 443-453, Mar. 2013.

BRASIL. Ministério da Ciência e Tecnologia. Plano de Ação 2007-2010: ciência, tecnologia e inovação para o desenvolvimento nacional. Brasília: Ministério da Ciência e Tecnologia, 2007. - Ministério da Ciência, Tecnologia e Inovação. Estratégia Nacional de Ciência, Tecnologia e Inovação 2012-2015. Brasília: MCTI, 2012.

CALVERT, J.; PATEL, P. University-industry research collaborations in the UK: bibliometric trends. Science and Public Policy, v. 30, n. 2, p. 85-96, 2003.

CHAVES, C. V. et al. The point of view of firms in Minas Gerais about the contribution of universities and research institutes to R\&D activities. Research Policy, v. 41, n. 9, p. 1683-1695, 2012.

COCKBURN, I. M.; HENDERSON, R. M. Absorptive capacity, coauthoring behavior, and the organization of research in drug discovery. The Journal of Industrial Economics, v. 46, n. 2, p. 157-182, 1998.

COHEN, W. M.; NELSON, R. R.; WALSH, J. P. Links and impacts: The influence of public research on industrial R\&D. Management Science, v. 48, n. 1, p. 1-23, 2002. 
DANTAS, E.; BELL, M. The co-evolution of firm-centered knowledge networks and capabilities in late industrializing countries: the case of Petrobras in the offshore oil innovation system in Brazil. World Development, v. 39, n. 9, p. 1570-1591, Sep. 2011.

DUTRÉNIT, G. Interactions between public research organisations and industry in Latin America: a study on channels and benefits from the perspective of firms and researchers. Science and Public Policy, v. 37, n. 7, p. 471-472, Aug. 2010.

DUTRÉNIT, G.; ARZA, V. Channels and benefits of interactions between public research organisations and industry: comparing four Latin American countries. Science and Public Policy, v. 37, n. 7, p. 541-553, Aug. 2010.

EUROPEAN COMMISSION. Innovation Union Scoreboard. Brussels: [s.n.]. Innovation Union Scoreboard 2015. Brussels: [s.n.].

FAPESP. Science, Technology \& innovation indicators in the State of São Paulo/Brazil 2010. São Paulo: [s.n.].

FERNANDES, A. C. et al. Academy-industry links in Brazil: evidence about channels and benefits for firms and researchers. Science and Public Policy, v. 37, n. 7, p. 485-498, Aug. 2010.

FERREIRA, M. L. A.; RAMOS, R. R. Making university-industry technological partnerships work: a case study in the Brazilian oil innovation system. Journal of Technology Management \& Innovation, v. 10, n. 1, p. 173-187, 2015.

FREEMAN, C.; SOETE, L. The economics of industrial innovation. Cambridge, MA: The MIT Press, 1997.

FURTADO, A. T. Mudança institucional e inovação na indústria brasileira de petróleo. Revista Brasileira de Energia, v. 9, p. 1-12, 2003.

Institutional arrangements and science and technology policies in the energy sector. In: PRIME-LATIN AMERICA CONFERENCE. Anais...Cidade do México, 2008. v. 1, p. $1-24$.

FURTADO, A. T.; FREITAS, A. G. The catch-up strategy of Petrobras through cooperative R\&D. The Journal of Technology Transfer, v. 25, n. 1, p. 23-36, 2000.

GARCIA, R. et al. Looking at both sides: how specific characteristics of academic research groups and firms affect the geographical distance of university-industry linkages. Regional Studies, Regional Science, v. 2, n. 1, p. 517-533, 2015.

GIELFI, G. G. et al. User-producer interaction in the Brazilian oil industry: the relationship between Petrobras and its suppliers of wet christmas tree. Journal of Technology Management \& Innovation, v. 8, Special Issue ALTEC, p. 117-127, 2013. 
GIULIANI, E.; ARZA, V. What drives the formation of "valuable" university-industry linkages? Insights from the wine industry. Research Policy, v. 38, n. 6, p. 906-921, Jul. 2009. IBGE. Pesquisa de Inovação - PINTEC. Brasília, [s.n.]. Disponível em: <www.ipea.gov.br>. JACKSON, M. O. Social and economic networks. New Jersey: Princeton Univerity Press, 2008. KATZ, J. S.; MARTIN, B. R. What is research collaboration? Research Policy, v. 26, n. 1, p. 1-18, Mar. 1997.

KLEVORICK, A. K. et al. On the sources and significance of interindustry differences in technological opportunities. Research Policy, v. 24, n. 2, p. 185-205, Mar. 1995.

LAURSEN, K.; SALTER, A. Searching high and low: what types of firms use universities as a source of innovation? Research Policy, v. 33, n. 8, p. 1201-1215, 2004.

LIMA, M. F. C.; SILVA, M. A. Inovação em petróleo e gás no Brasil: a parceria Cenpes-Petrobras e Coppe-UFRJ. Sociedade e Estado, v. 27, n. 1, p. 97-115, 2012.

MANSFIELD, E. Academic research underlying industrial innovations: sources, characteristics, and financing. The Review of Economics and Statistics, v. 77, n. 1, p. 55-65, 1995. MAZZOLENI, R.; NELSON, R. R. Public research institutions and economic catch-up. Research Policy, v. 36, n. 10, p. 1512-1528, Dec. 2007.

MAZZUCATO, M. The entrepreneurial state: debunking the public vs, private myth in risk and innovation. London: Anthem Press, 2013.

MEYER-KRAHMER, F.; SCHMOCH, U. Science-based technologies: university-industry interactions in four fields. Research Policy, v. 27, n. 8, p. 835-851, Dec. 1998.

MOWERY, D. C.; SAMPAT, B. N. Universities in National Innovation Systems. In: FAGERBERG, J.; MOWERY, D. C.; NELSON, R. R. (Ed.). The Oxford handbook of innovation. Oxford: Oxford University Press, 2005. p. 209-239.

OECD. University-enterprise relations in OECD member countries. Paris: [s.n.]. . Commercialising Public Research. [s.l: s.n.].

. Brazil. In: OECD Science, Technology and Industry Outlook 2014. Paris: OECD Publishing, 2014. p. 280-283.

PAVITT, K. What makes basic research economically useful? Research Policy, v. 20, n. 2, p. 109-119, Apr. 1991.

PEREIRA, N. M. Fundos setoriais: avaliação das estratégias de implementação e gestão. Brasília: Ipea, 2005 (Texto para discussão, n.1136). 
PEREIRA, N. M.; FIGUEIREDO, S. P. Experiências de apoio à inovação tecnológica setorial. Journal of Technology Management \& Innovation, v. 1, n. 3, p. 74-80, 2006.

PERKMANN, M.; WALSH, K. The two faces of collaboration: impacts of university-industry relations on public research. Industrial and Corporate Change, v. 18, n. 6, p. 1033-1065, Jun. 2009.

POLETTO, C. A.; ARAÚJO, M. A. D. de; MATA, W. da. Gestão compartilhada de P\&D: o caso da Petrobras e a UFRN. Revista de Administração Pública, v. 45, n. 4, p. 1095-1117, ago. 2011.

RAPINI, M. S. Interação universidade-empresa no Brasil: evidências do Diretório dos Grupos de Pesquisa do CNPq. Revista de Economia Contemporânea, v. 11, n. 1, p. 99-117, 2007.

RAPINI, M. S. et al. University-industry interactions in an immature system of innovation: evidence from Minas Gerais, Brazil. Science and Public Policy, v. 36, n. 5, p. 373-386, 2009.

RAPINI, M. S.; OLIVEIRA, V. P. de; SILVA NETO, F. C. C. A natureza do financiamento influencia na interação universidade-empresa no Brasil? Revista Brasileira de Inovação, v. 13, n. 1, p. 77-108, 2014.

RIBEIRO, C. G.; FURTADO, A. T. Government procurement policy in developing countries: the case of Petrobras. Science Technology \& Society, v. 19, n. 2, p. 161-197, 2014.

ROCHA, F. Does governmental support to innovation have positive effect on R\&D investments? Evidence from Brazil. Revista Brasileira de Inovação, v. 14, n. especial, p. 37-60, 2015.

SALTER, A. J.; MARTIN, B. R. The economic benefits of publicly funded basic research: a critical review. Research Policy, v. 30, n. 3, p. 509-532, 2001.

SCHARTINGER, D. et al. Knowledge interactions between universities and industry in Austria: sectoral patterns and determinants. Research Policy, v. 31, n. 3, p. 303-328, Mar. 2002.

SUSLICK, S. B. Strategic university-industry partnership in petroleum: the case of Cepetro/ Unicamp as a Brazilian innovative experience. Brazilian Journal of Petroleum and Gas, v. 1, n. 2, p. 59-66, 2007.

SUZIGAN, W.; ALBUQUERQUE, E. M. The underestimated role of universities for the Brazilian system of innovation. Revista de Economia Política, v. 31, n. 1, p. 3-30, 2011a.

A interação entre universidades e empresas em perspectiva histórica no Brasil. In: SUZIGAN, W.; ALBUQUERQUE, E. DA M. E; CARIO, S. A. F. (Ed.). Em busca da inovação: interação universidade-empresa no Brasil. Belo Horizonte, MG: Autêntica Editora, 2011b. p. 17-43. 
TIJSSEN, R. J. W. Measuring and evaluating science-technology connections and interactions. In: MOED, H. F.; GLÄNZEL, W.; SCHMOCH, U. (Ed.). Handbook of quantitative science and technology research: the use of publication and patent statistics in studies of S\&T systems. New York: Kluwer Academic Publisher, 2005. p. 695-715.

. Co-authored research publications and strategic analysis of public-private collaboration. Research Evaluation, v. 21, n. 3, p. 204-215, 28 Jul. 2012.

TIJSSEN, R. J. W.; VAN LEEUWEN, T. N.; VAN WIJK, E. Benchmarking universityindustry research cooperation worldwide: performance measurements and indicators based on co-authorship data for the world's largest universities. Research Evaluation, v. 18, n. 1, p. 13-24, Mar. 2009.

TURCHI, L.; DE NEGRI, F; DE NEGRI, J. A. (Ed.). Impactos tecnológicos das parcerias da Petrobras com universidades, centros de pesquisa e firmas brasileiras. Brasília: Ipea, 2013.

VELHO, L.; VELHO, P.; SAENZ, T. W. P\&D nos setores público e privado no Brasil: complementares ou substitutos? Parcerias Estratégicas, v. 19, p. 87-127, 2004.

VIEIRA, C. L. Brazil: new industry taxes boost science budget. Science, v. 291, n. 5509 , p. 1685-1685, Mar. 2001.

YUSUF, S.; NABESHIMA, K. How universities promote economic growth. Washington: The World Bank, 2006. 
Anex

Petrobras-university research collaboration trend analysis - 1980-1998

\begin{tabular}{|c|c|c|c|c|c|c|c|}
\hline $\begin{array}{c}\text { Publication } \\
\text { year }\end{array}$ & $\begin{array}{c}\text { Petrobras } \\
\text { output }\end{array}$ & UIC & $\begin{array}{l}\text { Nacional } \\
\text { UIC }\end{array}$ & $\begin{array}{c}\text { Interna- } \\
\text { tional } \\
\text { UIC }\end{array}$ & $\begin{array}{c}\text { UIC } \\
\text { intensity } \\
(\%)\end{array}$ & $\begin{array}{c}\text { Nacional } \\
\text { UIC } \\
\text { intensity } \\
(\%)\end{array}$ & $\begin{array}{l}\text { Interna- } \\
\text { tional UIC } \\
\text { intensity } \\
(\%)\end{array}$ \\
\hline 1980 & 1 & 0 & 0 & 0 & 0.0 & 0.0 & 0.0 \\
\hline 1981 & 1 & 0 & 0 & 0 & 0.0 & 0.0 & 0.0 \\
\hline 1982 & 1 & 1 & 0 & 1 & 100.0 & 0.0 & 100.0 \\
\hline 1983 & 1 & 1 & 1 & 0 & 100.0 & 100.0 & 0.0 \\
\hline 1985 & 1 & 1 & 0 & 1 & 100.0 & 0.0 & 100.0 \\
\hline 1986 & 6 & 1 & 0 & 1 & 17.0 & 0.0 & 17.0 \\
\hline 1987 & 1 & 0 & 0 & 0 & 0.0 & 0.0 & 0.0 \\
\hline 1988 & 3 & 2 & 1 & 2 & 67.0 & 33.0 & 67.0 \\
\hline 1989 & 1 & 0 & 0 & 0 & 0.0 & 0.0 & 0.0 \\
\hline 1990 & 4 & 0 & 0 & 0 & 0.0 & 0.0 & 0.0 \\
\hline 1991 & 9 & 4 & 4 & 0 & 44.0 & 44.0 & 0.0 \\
\hline 1992 & 7 & 5 & 3 & 3 & 71.0 & 43.0 & 43.0 \\
\hline 1993 & 7 & 2 & 0 & 2 & 29.0 & 0.0 & 29.0 \\
\hline 1994 & 14 & 10 & 6 & 5 & 71.0 & 43.0 & 36.0 \\
\hline 1995 & 14 & 10 & 6 & 4 & 71.0 & 43.0 & 29.0 \\
\hline 1996 & 7 & 6 & 4 & 2 & 86.0 & 57.0 & 29.0 \\
\hline 1997 & 25 & 17 & 13 & 5 & 68.0 & 52.0 & 20.0 \\
\hline 1998 & 21 & 17 & 9 & 9 & 81.0 & 43.0 & 43.0 \\
\hline
\end{tabular}


Petrobras-university research collaboration trend analysis - 1999-2014

\begin{tabular}{|c|c|c|c|c|c|c|c|}
\hline $\begin{array}{c}\text { Publication } \\
\text { year }\end{array}$ & $\begin{array}{c}\text { Petrobras } \\
\text { output }\end{array}$ & UIC & $\begin{array}{c}\text { Nacional } \\
\text { UIC }\end{array}$ & $\begin{array}{c}\text { Interna- } \\
\text { tional } \\
\text { UIC }\end{array}$ & $\begin{array}{c}\text { UIC } \\
\text { intensity } \\
(\%)\end{array}$ & $\begin{array}{c}\text { Nacional } \\
\text { UIC } \\
\text { intensity } \\
(\%)\end{array}$ & $\begin{array}{l}\text { Interna- } \\
\text { tional UIC } \\
\text { intensity } \\
(\%)\end{array}$ \\
\hline 1999 & 42 & 28 & 19 & 11 & 67.0 & 45.0 & 26.0 \\
\hline 2000 & 34 & 25 & 19 & 7 & 74.0 & 56.0 & 21.0 \\
\hline 2001 & 56 & 40 & 30 & 12 & 71.0 & 54.0 & 21.0 \\
\hline 2002 & 43 & 35 & 29 & 11 & 81.0 & 67.0 & 26.0 \\
\hline 2003 & 38 & 33 & 27 & 14 & 87.0 & 71.0 & 37.0 \\
\hline 2004 & 62 & 50 & 45 & 13 & 81.0 & 73.0 & 21.0 \\
\hline 2005 & 59 & 48 & 42 & 10 & 81.0 & 71.0 & 17.0 \\
\hline 2006 & 67 & 63 & 54 & 14 & 94.0 & 81.0 & 21.0 \\
\hline 2007 & 66 & 63 & 57 & 11 & 95.0 & 86.0 & 17.0 \\
\hline 2008 & 94 & 83 & 73 & 17 & 88.0 & 78.0 & 18.0 \\
\hline 2009 & 91 & 86 & 76 & 17 & 95.0 & 84.0 & 19.0 \\
\hline 2010 & 127 & 112 & 102 & 21 & 88.0 & 80.0 & 17.0 \\
\hline 2011 & 111 & 104 & 93 & 23 & 94.0 & 84.0 & 21.0 \\
\hline 2012 & 127 & 108 & 94 & 26 & 85.0 & 74.0 & 20.0 \\
\hline 2013 & 119 & 113 & 102 & 23 & 95.0 & 86.0 & 19.0 \\
\hline 2014 & 171 & 158 & 146 & 35 & 92.0 & 85.0 & 20.0 \\
\hline Total & 1,431 & 1,226 & 1,055 & 300 & 86.0 & 74.0 & 21.0 \\
\hline
\end{tabular}

Source: Authors based on CWTS Web of Science database 